\title{
Effect of Secondary Structures of Protein on Determination of Protein Content by Near Infrared Spectroscopy
}

\author{
Hiromi Kamishikiryo-Yamashita*, Megumi Tatara**, \\ Hitoshi TaKamura ${ }^{* *}$ and Teruyoshi MatoBa ${ }^{* * . \dagger}$ \\ * Division of Human Life and Environmental Science, Graduate School of Human Culture, and \\ ** Department of Food Science and Nutrition, Nara Women's University, Nara 630 \\ tTo whom correspondence should be addressed.
}

\begin{abstract}
Characteristics of the absorption at $2170 \mathrm{~nm}$, which is due to peptide bonds, were investigated using various proteins. The intensities of the absorption due to peptide bonds were different depending on the kinds of proteins examined. The absorption of bovine serum albumin at $2170 \mathrm{~nm}$ decreased by reducing its disulfide (S-S) bonds. The absorption of poly-L-glutamic acid in the $\boldsymbol{\alpha}$-helix state at $2170 \mathrm{~nm}$ was stronger than that in the random coil state. These results suggest that the secondary structures of proteins affect the absorption at $2170 \mathrm{~nm}$. The extent of contribution of the secondary structures to the absorption intensity was statistically predicted using 9 proteins which have different contents in secondary structures such as $\alpha$-helix, $\beta$-sheet and random coil structures. It was found that the relative extent of the $\alpha$-helix, $\beta$-sheet and random coil structures to the absorption at $2170 \mathrm{~nm}$ was approximately $2: 1: 1$.
\end{abstract}

\section{Introduction}

The quantitative determination of various food constituents by near infrared (NIR) spectroscopy has many advantages such as simple operation, rapid measurement and nondestructive analysis, compared with conventional chemical analysis ${ }^{1)}$. However, NIR spectroscopy has disadvantages from the viewpoint that it is an empirical procedure and needs a number of samples to obtain a stable calibration; that is, a calibration for one item of food cannot be applied to other items. In order to remove such disadvantages, it is necessary to gain fundamental information regarding the NIR absorption. Protein is one of the most popular compositions which can be determined by the NIR spectroscopy. There have been many investigations about the determination of protein content by NIR spectroscopy ${ }^{2) \sim 7)}$. The most important application is the determination of the protein content of wheat. At present, this method is widely used for routine analysis in many countries $^{8) 9}$. This measurement provides an accurate determination using a calibration equation developed by multiple regression analysis. However, the wavelengths used for the calibration have not been yet clearly assigned. In our previous report, we investigated the effect of co-existing materials and measuring conditions on the characteristic absorption for determining protein content using bovine serum albumin (BSA) as the model protein, and elucidated that the absorption at $2170 \mathrm{~nm}$ due to peptide bonds is the most suitable ${ }^{10)}$.

In order to apply the absorption at $2170 \mathrm{~nm}$ for determining the content of various proteins, it is necessary to investigate how the absorption at $2170 \mathrm{~nm}$ is influenced by protein structures. The purpose of this study is to evaluate the absorption intensity at $2170 \mathrm{~nm}$ of various proteins and to investigate the effect of the secondary structures of proteins on the absorption intensity around $2170 \mathrm{~nm}$.

\section{Materials and Methods}

NIR transmittance measurement

NIR transmittance spectra were recorded 
using an NIR Systems (Pacific Scientific) Model 6250 Research Composition Analyzer in wavelength region from $1100 \mathrm{~nm}$ to $2500 \mathrm{~nm}$ at intervals of $2 \mathrm{~nm}$.

The transmittance measurement was carried out with a quartz glass cell (light path, $1 \mathrm{~mm}$ ) under $30^{\circ} \mathrm{C}$. The spectra were collected as the average value of 50 scans in the wavelength region, and recorded as $\log (1 / \mathrm{T})$ which was defined as absorbance ( $T$; transmittance). A quartz glass cell filled with water was used as the standard reference to calculate $\log (1 / \mathrm{T})$.

\section{Materials}

Bovine serum albumin (BSA, fraction V), and cytochrome $c(85-100 \%)$ were obtained from Nacalai Tesque (Kyoto, Japan). Ovalbumin (grade V), lysozyme (grade I), myoglobin (95$100 \%$ ), ribonuclease (Type 1-A), chymotrypsin (Type II), subtilisin (Type XXVII), trypsin (Type III) and pepsin (crystallized and lyophilized powder) were obtained from Sigma Chemical Co. (St. Louis, MO, U.S.A.). Poly-Lglutamic acid sodium salt was purchased from Peptide Institute (Osaka, Japan). All other chemicals were of analytical grade.

\section{Peptide bond content}

Protein content was determined by the UV method. The spectrophotometer used was a Hitachi 200-20. The absorption coefficient $\left(\mathrm{A}^{1 \%}\right.$ at $280 \mathrm{~nm}$ ) of each protein was as follows : BSA, 6.6 ; ovalbumin, 7.35 ; lysozyme, 26.9 ; myoglobin, 19 ; cytochrome $c 17.1$; ribonuclease, 7.1 (at $278 \mathrm{~nm}$ ); $\alpha$-chymotrypsin, 20.8 ; subtilisin, 11.7 ; pepsin, 13.2 ; trypsin, 15.4 . The peptide bond content (the number of amino acid residues per molar) was calculated on the basis of the primary structure and protein content of each protein.

Reduction of disulfide bond in BSA

The reaction mixture contained $5 \%$ BSA and $20 \mathrm{mM}$ dithiothreitol. The reaction was carried out at $30^{\circ} \mathrm{C}$ in a quartz cell attached to the NIR instrument. The NIR measurement was performed at 10 -minute intervals.

\section{Results and Discussion}

Relationship between the peptide bond content and the absorption at $2170 \mathrm{~nm}$ of proteins

The relationship between the number of amino acid residues (peptide bond molar content) and the value of the second derivative $\left[\mathrm{d}^{2} \log (1 / \mathrm{T})\right]$ around $2170 \mathrm{~nm}$ was investigated using BSA, ovalbumin and lysozyme, as shown in Fig. 1. Although high correlations were observed between the peptide bond content and $-\mathrm{d}^{2} \log (1 / \mathrm{T})$, the regression coefficient (slope) was different depending on the kind of proteins. In our preliminary experiment, when these proteins were denatured by guanidine hydrochloride $(4.2 \mathrm{M})$, the intensities of the absorptions around $2170 \mathrm{~nm}$ due to their peptide bonds were the same (data not shown). However, the absorption intensities around $2170 \mathrm{~nm}$ per peptide bond were different among these proteins, suggesting that the absorption around $2170 \mathrm{~nm}$ may be affected by the changes in the secondary structures of a protein, not by the changes in their primary structure.

\section{Effect of structure}

In order to clarify the reason why the absorption intensity around $2170 \mathrm{~nm}$ of each protein was different, we investigated the change of $\mathrm{d}^{2} \log (1 / \mathrm{T})$ at $2170 \mathrm{~nm}$ caused by the conformational change of protein using BSA as the model protein. The reduction of the disul-

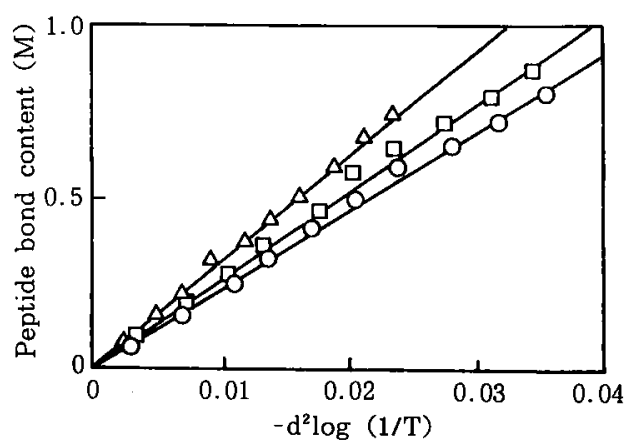

Fig. 1 Relationship between peptide bond content and $-d^{2} \log (1 / T)$ at $2170 \mathrm{~nm}$ of proteins

$\triangle$; ovalbumin, $\square$; lysozyme, $\mathrm{O}$; BSA 
fide bond has been known to cause a change in protein structure ${ }^{11)}$. Accordingly, the disulfide bond of BSA was reduced in the presence of dithiothreitol, and the second derivative spectra of BSA during the reduction were recorded at 10-minute intervals. The spectra are shown in Fig. 2. The absorption at 2170 $\mathrm{nm}$ became weaker with the elapse of reaction time. This result suggests that the absorbance at $2170 \mathrm{~nm}$ is affected by conformational change in the protein.

Effect of secondary structural change on the absorption at $2170 \mathrm{~nm}$ of poly-L-glutamic acid

It has been known that poly-L-glutamic acid has a random coil structure at $\mathrm{pH} 7.5$ and $\alpha$-helical structure at $\mathrm{pH} 4.4^{12}$. In order to investigate how the secondary structural changes affect the absorption at $2170 \mathrm{~nm}$, the second derivative spectra of $1 \%$ poly-L-glutamic acid solutions at pH 7.5 and $\mathrm{pH} 4.4$ were examined (Fig. 3). The absorption intensity at $2170 \mathrm{~nm}$ of the polypeptide in $\alpha$-helical structure $(\mathrm{pH}$ 4.4) was much stronger than that in the random coil structure ( $\mathrm{pH}$ 7.5). This result suggests that the absorption at $2170 \mathrm{~nm}$ is significantly affected by the secondary structural change of proteins.

Contribution of secondary structures of proteins to the absorption around $2170 \mathrm{~nm}$

The extent of the contribution of the secondary structure to the absorption around $2170 \mathrm{~nm}$ was investigated using nine kinds of proteins such as lysozyme, myoglobin, cytochrome $c$, ribonuclease, chymotrypsin, subtilisin, trypsin, pepsin and ovalbumin. A simple linear regression was run to obtain a correlation between peptide bond content and the $\mathrm{d}^{2} \log (1 / \mathrm{T})$ around $2170 \mathrm{~nm}$. The regression coefficients obtained are summarized in Table 1. In order to obtain the extent of contribution of the secondary structures to the $\mathrm{d}^{2} \log (1 / \mathrm{T})$ around $2170 \mathrm{~nm}$, the following equation was developed :

$$
W_{n}=a \cdot X_{n}+b \cdot Y_{n}+c \cdot Z_{n}
$$

where $X_{n}, Y_{n}$ and $Z_{n}$ are the contents $(\%)$ of the $\alpha$-helix, $\beta$-sheet and random coil structures, respectively. $W_{n}$ is the regression coefficient

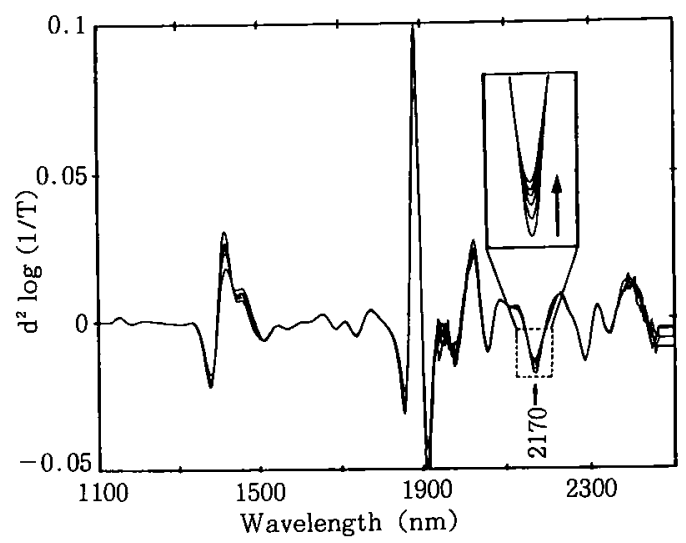

Fig. 2 Effect of the reduction of disulfide bond in BSA on the absorption at $2170 \mathrm{~nm}$.

The arrow in the inset shows the elapse of the reducing reaction time $(0-60 \mathrm{~min})$.

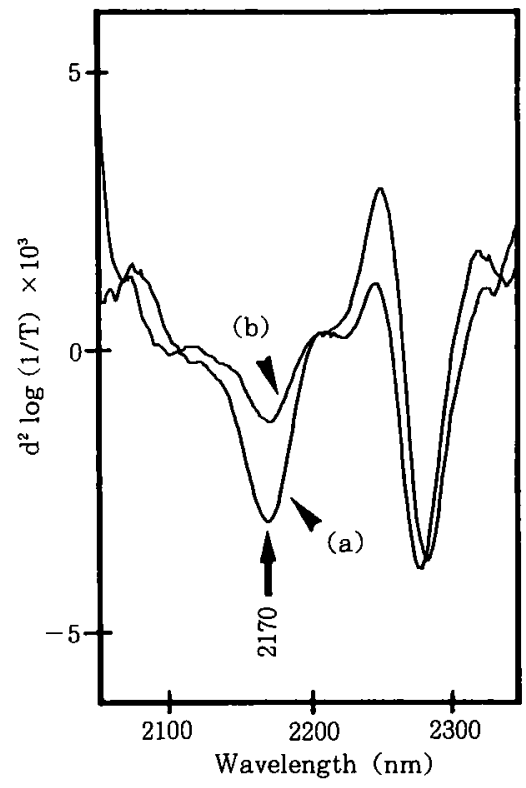

Fig. 3 Effect of secondary structural change of poly-L-glutamic acid on the absorption at $2170 \mathrm{~nm}$

(a), $\alpha$-helix (pH 4.4) ; (b), random coil structure (pH 7.5) 
Table 1 Relationship between peptide bond content and the $d^{2} \log (1 / T)$ at $2170 \mathrm{~nm}$

\begin{tabular}{lcccc}
\hline \hline \multicolumn{1}{c}{ Protein } & $\mathrm{A}^{\mathrm{a})}$ & $\mathrm{B}^{\mathrm{a})}$ & $\mathrm{R}^{\mathrm{b})}$ & $\mathrm{SE}^{\mathrm{c}}$ \\
\hline Lysozyme & 3.97 & 0.0243 & -0.992 & 0.0972 \\
Myoglobin & 4.73 & -0.00815 & -1.000 & 0.0220 \\
Cytochrome c & 3.34 & -0.0134 & -0.999 & 0.0262 \\
Ribonuclease & 3.09 & 0.0383 & -1.000 & 0.0161 \\
Chymotrypsin & 2.87 & 0.0109 & -1.000 & 0.0146 \\
Subtilisin & 3.53 & -0.00564 & -1.000 & 0.0143 \\
Trypsin & 2.81 & 0.0234 & -0.999 & 0.0293 \\
Pepsin & 2.49 & 0.0123 & -0.999 & 0.0324 \\
Ovalbumin & 3.23 & -0.00662 & -0.999 & 0.0387 \\
\hline
\end{tabular}
a) $-\mathrm{d}^{2} \log (1 / \mathrm{T})=\mathrm{A} \cdot($ peptide bond content $)+\mathrm{B}$
b) Correlation coefficient
c) Standard error

Table 2 Secondary structure content of various proteins

\begin{tabular}{lccc}
\hline \hline \multirow{2}{*}{ Protein } & \multicolumn{3}{c}{ Secondary structure content $(\%)^{*}$} \\
\cline { 2 - 4 } & $\alpha$-Helix & $\beta$-Sheet & Random coil \\
\hline Lysozyme & 36 & 41 & 23 \\
Myoglobin & 78 & 12 & 10 \\
Cytochrome c & 38 & 17 & 45 \\
Ribonuclease & 24 & 41 & 35 \\
Chymotrypsin & 10 & 54 & 36 \\
Subtilisin & 30 & 30 & 40 \\
Trypsin & 13.45 & 65.47 & 21.08 \\
Pepsin & 9.8 & 85.6 & 4.6 \\
Ovalbumin & 30 & 49 & 21 \\
\hline
\end{tabular}

${ }^{*}$ The content was cited from the literatures ${ }^{13)-16)}$.

(A) in Table 1. The coefficients, a, b and $c$ in the equation are the extent of contribution of the $\alpha$-helix, $\beta$-sheet and random coil structures, respectively. In other words, the relative magnitude of these three coefficients is an index of the extent of contribution of each secondary structure to the absorption at 2170 $\mathrm{nm}$. The nine kinds of proteins of which secondary structures are well known is shown in Table 2 and was used for the calculation. These data were cited from the literatures reported by other researchers $\left.{ }^{13)} \sim 16\right)$. The coefficients of $a, b$ and $c$, estimated by a multiple regression analysis, were $5.42 \times 10^{-2}, 2.34 \times 10^{-2}$ and $2.64 \times 10^{-2}$, respectively. This result shows that the extent of the contribution of $\alpha$-helix, $\beta$-sheet and random coil structures to the absorption is approximately $2: 1: 1$, in relative magnitude.

From these results described above, it is concluded that the NIR determination of protein content using the absorption at $2170 \mathrm{~nm}$ is affected by the conformational changes in proteins. Therefore, the measurement at $2170 \mathrm{~nm}$ could be useful for monitoring the extent of denaturation of proteins in foods during processing and cooking.

\section{References}

1) Osborne, B.G. and FEARN, T. : Near Infrared 
d Spectroscopy in Food Analysis. Longman Scientific Technical, Harlow (1986).

2) Miller, B.S., Pomeranz, Y., Thompson, W.O., Nolan, T.W., Hughes, J.W., Davis, G., Jackson, N.G. and FULK, D.W. : Cereal Foods World., 23, 198 (1978).

3) Osborne, B.G., Barrett, G.M., Cauvain, S.P. and FEARN, T. : J. Sci. Food Agric, 35, 940 (1984).

4) Orman, B.A. and Schumann, R.A.Jr. : J.Agric. . Food Chem., 39, 883 (1991).

5) Panford, J.A., Williams, P.C. and deMan, J.M. : J. Am. Oil Chem. Soc., 65, 1627 (1988).

6) Wehling, R.L., Pierce M.M. and Froning, G.W. : J. Food Sci., 53, 1356 (1988).

7) Saio, K., Cho, R.K., Akiyama, Y. and Iwamoto, M. : Rep. Natl. Food Res. Inst., 51, 11 (1987).

8) Williams, P.C. : Cereal Chem., 56, 169 (1979).

9) Osborne, B.G., Douglas., S. and Fearn, T. : $J$. Food Tech., 17, 355 (1982).

10) KamishikiRyo, H., HaSEgawa, K., and Matoba, T. : Nippon Shokuhin Kogyo Gakkaishi, 38, 850 (1991).

11) Tanford, C., Kawahara, K., Lapanje, S., HoOKER, T.M. Jr., ZARLENGo, M.H., SALAHUdDiN, A., Aune; K.C. and Takagl, T. : J. Am. Chem. Soc., 89, 5023 (1967).

12) AldER, A.J., GREENFIELd, N.J. and FASMAN, G.D.: Methods in Enzymology. Academic Press, New York. Vol. 27 (1973).

13) Hennessey, J.P. Jr. and Johnson, W.C. Jr. : Biochem., 20, 1085 (1981).

14) ReAD, R.J. and James, M.N.G. : J. Mol. Biol., 200, 523 (1988).

15) Sielecki, A.R., Fedorov, A.A, Boodhoo, A., ANDREEVA, N.S. and JAMES, M.N.G.: J. Mol.
Biol., to be published.

16) Stein, P.E., Leslie, A.G.W., FinCh, J.T. and CARrell, R.W. : J. Mol. Biol., 221, 941 (1991).

(Received, Mar. 17. 1993)

\section{近赤外分光法によるタンパク質の定量測定に対する タンパク質の二次構造の影響 \\ 山下（上敷領）広美*・多々良恵** 高村仁知** $\cdot$ 的場輝佳 $* *$ \\ *奈良女子大学人間文化研究科, \\ ** 奈良女子大学家政学部食物学科 \\ （㣙0 奈良県奈良市北魚屋西町）}

近赤外分光法によるタンパク質含量の測定を様々な種 類のタンパク質に適用するために，種々のタンパク質お よびポリペプチドを用いて，ペプチド結合に由来する $2170 \mathrm{~nm}$ の吸収特性について検討した。ペプチド結合数 と $2170 \mathrm{~nm}$ の吸収強度との関係を比較した結果, ペフ チド結合当たりの相対吸収強度には，タンパク質の種類 により差がみられた．次に，牛血清アルプミンのS-S 結 合を還元して変性させると, $2170 \mathrm{~nm}$ の吸収強度が弱く なった. また， $\mathrm{pH}$ を変化させることによりポリーLーグル 夕ミン酸の二次構造を变化させた場合む, $2170 \mathrm{~nm}$ の吸 収強度が变化した。このことから，2170 nm の吸収強度 は二次構造により影響を受けると推測された。 そこで， 二次構造既知のタンパク質を用いて，二次構造含量と $2170 \mathrm{~nm}$ の吸収強度との関係を統計的に解析した結果, $\alpha$-ヘリックス, $\beta$-構造, ランダム構造は, $2170 \mathrm{~nm}$ の相 対吸収強度に対してそれぞれ $2: 1: 1$ の割合で寄与する ことが明らかとなった。 